\title{
MODEL KOMUNIKASI INTERNASIONAL PERJANJIAN HUDAIBIYAH SEBAGAI METODE DAKWAH ERA MASYARAKAT EKONOMI ASEAN (MEA)
}

\author{
Sudir Koadhi \\ Moh. Natsir Mahmud \\ Muliaty Amin \\ Unismu Makasar \\ e-mail: konawe07@gmail.com
}

\begin{abstract}
The discourse of the da'wah method in the framework of Southeast Asian regionalism is a matter purely in contact with the reasoning of mad'u life, the fulfilment of the essential elements of life (zimam al-hayah). Context restores the idea of Muslims passing into the era of the ASEAN Economic Community (MEA) which began to be applied gradually since 2015 with the motto of one vision, one identity and one community, becoming the embryo of the construction of Hudaibiyah international communication model for the first time. The main idea of the construction of the international communication model of this Hudaibiyah Treaty which is a representation of the necessity of syumuliyyat al-Islam is wus'ah maidan al-da'wah (an expanding dakwah field). The construction of the international communication model The Hudaibiyah Treaty is very relevant to be put forward as the primary tool in formulating the method of da'wa era of the MEA.
\end{abstract}

\section{Key words:}

Dakwah, Communication, Society Of Asean Economy 


\section{Abstrak}

Diskursus metode dakwah dalam bingkai regionalisme Asia Tenggara adalah persoalan yang murni bersentuhan dengan nalar kehidupan mad'u, yaitu pemenuhan unsur-unsur pokok dalam kehidupan (zimam al-hayah). Konteks mengembalikan izzah kaum muslimin melintas ke era Masyarakat Ekonomi ASEAN (MEA) yang mulai diberlakukan secara bertahap sejak 2015 dengan motto one vision, one identity and one community, menjadi embrio lahirnya konstruksi model komunikasi internasional Perjanjian Hudaibiyah untuk pertama kali. Gagasan utama dari konstruksi model komunikasi internasional Perjanjian Hudaibiyah ini yang merupakan representasi dari keniscayaan syumuliyyat al-Islam adalah wus'ah maidan al-da'wah (medan dakwah yang mengalami perluasan). Konstruksi model komunikasi internasional Perjanjian Hudaibiyah sangat relevan untuk dikedepankan sebagai piranti utama dalam merumuskan metode dakwah era MEA.

\section{Kata Kunci:}

Dakwah, Komunikasi, Masyarakat Ekonomi Asean 


\section{A. Pendahuluan}

Dalam disiplin Ilmu Komunikasi, model komunikasi internasional merupakan gabungan dua term yang berbeda, yaitu model komunikasi dan komunikasi internasional. Secara aplikatif, praktek komunikasi internasional menggunakan empat pendekatan dominan, yaitu: pendekatan idealistik-humanistik, kepengikutan politik baru (political proselytization), informasi sebagai kekuatan ekonomi, dan kekuatan politik.

Keempat pendekatan tersebut masing-masing mempunyai kekuatan dan kelemahan, sehingga yang paling ideal dalam mengaplikasikan komunikasi internasional menggunakan pendekatan yang integral, dan tidak menonjolkan kepentingan sepihak, sehingga tidak berpotensi mengeksploitasi negara-negara lemah, atau negara-negara yang belum memadai sarana informasi dan komunikasinya.

Adapun model komunikasi sebagaimana yang dikemukakan oleh Deddy Mulyana, merupakan presentasi suatu fenomena komunikasi baik nyata maupun abstrak, dengan menonjolkan unsur-unsur terpenting fenomena tersebut dan menghilangkan rincian komunikasi yang tidak perlu. $^{2}$

Model komunikasi merupakan alat untuk mempermudah menjelaskan fenomena komunikasi, yang mendeskripsikannya secara ideal mengenai apa yang dibutuhkan untuk terjadinya komunikasi. Dengan demikian dapat dipahami bahwa ada kemungkinan beberapa nuansa komunikasi yang lain akan terabaikan, tidak terjelaskan dalam model tersebut. Hal ini disebabkan karena model komunikasi hanya merepresentasikan secara abstrak ciri-ciri penting, dan menghilangkan rincian komunikasi yang tidak perlu dalam dunia nyata. ${ }^{3}$

\footnotetext{
'Mohammad Shoelhi, Diplomasi: Praktik Komunikasi Internasional (Cet. I; Bandung: Simbiosa Rekatama Media, 2011 1), 5.

${ }^{2}$ Deddy Mulyana, Ilmu Komunikasi: Suatu Pengantar (Cet.XIX; Bandung: Remaja Rosdakarya, 2015), 131-132. Lihat: Mohammad Shoelhi, Komunikasi Internasional, 7.

${ }^{3}$ Mary B. Cassata dan Molefi K. Asante, Mass Communication: Principles and Practices (New York: Macmillan, 1979), 63-64; dikutip dalam Deddy Mulyana, Ilmu Komunikasi, 132.
} 
B. Aubrey Fisher mengatakan, model adalah analogi yang mengabstraksikan dan memilih bagian, unsur, sifat, atau komponen yang penting dari fenomena yang dijadikan model. ${ }^{4}$ Raymond S. Ross berpendapat bahwa model akan memberikan pandangan yang lain, berbeda, dan lebih dekat. Model juga akan menyediakan kerangka rujukan, menyarankan kesenjangan informasional, menyoroti problema abstraksi, dan menyatakan suatu problem dalam bahasa simbolik bila terdapat peluang untuk menggunakan gambar atau simbol. ${ }^{5}$

Oleh karena itu harus dipilih unsur-unsur tertentu yang akan dimasukkan ke dalam model untuk mengimplikasikan penilaian atas relevansi, yang pada gilirannya akan mengimplikasikan teori mengenai fenomena yang diteorikan. Dari sini model dapat berfungsi sebagai basis dari teori yang lebih kompleks, alat untuk menjelaskan teori dan menyarankan cara-cara untuk memperbaiki konsep-konsep. ${ }^{6}$

Berdasarkan uraian di atas, kajian ini akan membahas: Perjanjian Hudaibiyah perspektif hubungan internasional, model komunikasi internasional Perjanjian Hudaibiyah, dakwah Islam di kawasan ASEAN, dan metode dakwah era Masyarakat Ekonomi ASEAN (MEA) berdasarkan model komunikasi internasional Perjanjian Hudaibiyah.

\section{B. Perjanjian Hudaibiyah Perspektif Hubungan Internasional}

Perubahan pola hubungan internasional setelah berakhirnya Perang Dingin antara Amerika Serikat (AS) dan Uni Soviet (US) yang keduanya mewakili ideologi liberal dan ideologi komunis, dari sebelumnya bipolar (persaingan bernuansa militer antara dua ideologi tersebut) menjadi multipolar (persaingan atau konflik kepentingan ekonomi di antara

${ }^{4}$ B. Aubrey Fisher, Communication Theories. Teri. Soejono Trimo, Teori-teori Komunikasi (Bandung: Remaja Rosdakarya, 1986), h. 93-94. Lihat juga: Deddy Mulyana, Ilmu Komunikasi, 132.

${ }^{5}$ Raymond S. Ross, Speech Communication: Fundamentals and Practice. Edisi VI (New Jersey: Englewood Cliffs, 1983), 9; dikutip dalam Deddy Mulyana, I/mu Komunikasi, 135.

bJohn C. Zacharis dan Coleman C. Bender, Speech Communication: A Rational Approach (New York John Willey \& Sons, 1976), h. 34; dikutip dalam Deddy Mulyana, Ilmu Komunikasi,132. 
negara-negara di dunia). Dari high politics (fokus pada isu-isu politik dan keamanan) menjadi low politics (isu-isu hak asasi manusia, ekonomi, lingkungan hidup, terorisme, dan lain-lain). ${ }^{7}$ Dari hard power diplomacy menjadi soft power diplomacy dalam bentuk perundingan dan perjanjian kerja sama, ${ }^{8}$ menjadikan kajian Perjanjian Hudaibiyah sangat relevan dengan perubahan konflik dan persaingan ideologi di atas.

Relevansi tersebut semakin kuat ketika dikonstruksi dalam paradigma pluralis dalam hubungan internasional yang berkembang sangat pesat akhir-akhir ini. Paradigma pluralis melihat hubungan internasional tidak hanya terbatas pada hubungan antar negara saja, seperti pandangan paradigma realis. Kaum realisme memandang negara adalah aktor utama dalam hubungan internasional yang bersifat rasional dan monolith, sehingga tindakannya berdasarkan cost and benefit untuk kepentingan keamanan nasional yang berfokus pada struggle for power atau realpolitics. Oleh sebab itu, dasar dari interaksi dalam semua sistem internasional adalah anarkis, kompetitif, kadang konflik. Kerjasama dibangun hanya untuk kepentingan jangka pendek. Sehingga politik luar negeri suatu negara dalam paradigma realis menggunakan strategi penangkalan (detterence), perimbangan kekuatan (balance of power), dan aliansi-aliansi pertahanan (defence alliances). ${ }^{9}$

Berbeda dengan kaum realisme, kaum pluralisme memandang adanya aktor lain dalam hubungan internasional selain negara sebagai aktor utama dan aktor tunggal. Ada hubungan interdependensi antara individu dan antara kelompok kepentingan yang berimplikasi baik untuk mengatur interaksi dalam area-area isu hubungan internasional. ${ }^{10}$

\footnotetext{
${ }^{7}$ Conway W. Henderson, International Relations: Conflict and Cooperation at the Turn of $21^{\text {st }}$ Century (New York: McGraw-Hill International, 1998), 153-154.

${ }^{8}$ Anak Agung Banyu Perwita dan Yanyan Mochamad Yani, Pengantar Ilmu Hubungan Internasional (Cet. IV; Bandung: Remaja Rosdakarya, 2014), 5.

${ }^{9}$ Anak Agung Banyu Perwita dan Yanyan Mochamad Yani, Pengantar Ilmu Hubungan Internasional, 25.

${ }^{10}$ Anak Agung Banyu Perwita dan Yanyan Mochamad Yani, Pengantar Ilmu Hubungan Internasional, 26.
} 
Perjanjian Hudaibiyah" dilatarbelakangi oleh mimpi Rasulullah saw. memasuki kota Makkah dan țawaf mengitari Baitullah al-Haram. ${ }^{12}$ Mimpi tersebut menjadi basic design strategi untuk mendapatkan legitimasi hak beribadah di Baitullah al-Haram dalam bentuk pelaksanaan ibadah umrah.

Hijrah nabi telah mengubah konstelasi tantangan dan tekanan terhadap dakwah yang sebelumnya bersifat internal Quraisy menjadi eksternal. Dari sebelumnya berbentuk local social movement di Makkah menjadi regional military action di Jazirah Arab. Sebanyak tiga kali aksi militer dilancarkan oleh pihak musyrikin Quraisy dalam upaya menekan perkembangan geopolitik Islam: front Badar pada tahun ke-2 H (624 M) sebagai economica/ security action, ${ }^{13}$ front Uhud tahun ke-3 H (625 M), ${ }^{14}$ dan front Parit (khandaq) pada tahun ke-5 H (627 M). ${ }^{15}$

Akumulasi hasil dari ketiga aksi military action di atas, sangat jauh dari yang diharapkan. Sebaliknya, dalam bidang politik dan militer, pengaruh musyrikin Quraisy di kawasan Jazirah Arab semakin memudar. Banyak kabilah dan person yang sebelumnya merupakan sekutu musyrikin Quraisy, berbalik arah menjadi sekutu kaum muslimin dan memusuhi musyrikin Quraisy. Di bidang ekonomi, musyrikin Quraisy juga

\footnotetext{
${ }^{1}$ Teriadi pada bulan Dzulqa'dah tahun ke-6 H (Maret 628 M) para sejarawan ada yang menyebutnya Amru al-Hudaibiyyah, Qissah al-Hudaibiyyah, 'Umrah al-Hudaibiyyah, Sulh al-Hudaibiyyah, dan Gazwah al-Hudaibiyyah, menurut sudut pandang yang mereka gunakan dalam melihat peristiwa tersebut, tempat, waktunya, para pelaku yang terlibat, dan hasil atau tujuan yang hendak dicapai. Hafiz \bin Muhammad Abdullah al-Hakami, Marwiyyat Gazwah a/-Hudaibiyah (Madinah al-Munawwarah: Ihya' al-Turas\al-Islami, t.th), 14-16

${ }^{12} \mathrm{Al}$-Qurtubi mengutip pendapat Qatadah tentang mimpi Rasulullah saw. di Madinah pada tahun ke-6 H, yang menjadi basic design perang opini yang dilancarkan Rasulullah saw. mengawali Perjanjian Hudaibiyah. Abu 'Abdillah Muhammad bin Ahmad Abu Bakr Syams al-Din al-Qurtubi, Al-Jami' li Ahkam al-Qur'an. Tahqiq: Ahmad Barduni dan Ibrahim Atfis, Juz 8 (Cet. II; Kairo: Dar al-Kutub al-Misriyyah, 1964), 191.

${ }^{13}$ Safiyyurahman al-Mubarakfuri, Al-Rahiq al-Makhtum, h. 269-270. Lihat: https://id. wikipedia.org/wiki/Pertempuran Badar (diakses 8 November 2016)

${ }^{14}$ Abu Muhammad Abd al-Malik bin Hisyam, Al-Sirah al-Nabawiyyah, Juz 3 (Cet. II; Mesir: Mat|ba'ah al-Halabi wa Auladuh, 1375 H), 3-167. Lihat: https://id.wikipedia.org/wiki/Pertempuran Uhud (diakses 8 November 2016). Lihat juga: Safiyyurahman al-Mubarakfuri, Al-Rahiq al-Makhtum, h. 332.

${ }^{15}$ Abu Muhammad Abd al-Malik bin Hisyam, Al-Sirah al-Nabawiyyah, Juz 3, h. 165 167. Lihat: https://id.wikipedia.org/wiki/Pertempuran_Khandaq (diakses 8 November 2016). Lihat juga: Safiyyurahman al-Mubarakfuri, Al-Rahiq al-Makhtum, 393.
} 
mengalami kerugian yang cukup besar karena jalur perdagangan mereka ke Syam mendapatkan gangguan, khususnya setelah pertempuran di front Badar.

Perjanjian Hudaibiyah menghasilkan 7 klausul kesepakatan antara Rasulullah saw. dengan Suhail bin Amr perwakilan musyrikin Quraiys, ${ }^{16}$ yang jika dilihat sepintas lalu klausul-klausul tersebut tidak equal dan merugikan kaum muslimin. Setidaknya pada klausul yang mengharuskan kaum muslimin menunda keinginan keras mereka untuk melaksanakan umrah tahun tersebut, dan meng-qada-nya pada tahun berikutnya. Dan keharusan mengembalikan orang Quraisy Makkah yang masuk Islam dan melarikan diri ke Madinah tanpa izin orang tua atau walinya.

Meskipun demikian, klausul-klausul Perjanjian Hudaibiyah tetap ditaati oleh kaum muslimin, setidaknya hingga tahun ke- $8 \mathrm{H}$, ketika bani Bakar melakukan agresi terhadap bani Khuza'ah. Bani Bakar adalah sekutu musyrikin Quraisy sejak pengukuhan Perjanjian Hudaibiyah, sementara bani Khuza'ah adalah sekutu kaum muslimin. Agresi bani Bakar ini menjadi penyebab Rasulullah saw. menyatakan Perjanjian Hudaibiyah tidak berlaku lagi. ${ }^{17}$

Dalam kajian hubungan internasional, kepatuhan (complience) kaum muslimin terhadap klausul-klausul Perjanjian Hudaibiyah sangat jauh dari perspektif realisme. Dalam pandangan kaum realis, negara hanya akan taat pada hukum internasional jika bersesuaian dengan kepentingan

\footnotetext{
${ }^{16}$ Kesepakatan Perjanjian Hudaibiyah dirangkum ke dalam 4 klausul: (1) Rasulullah saw. Bersama dengan rombongannya harus pulang tahun ini. Tidak diperkenankan memasuki Makkah, kecuali tahun depan dan dengan syarat hanya tiga hari tanpa membawa senjata kecuali pedang yang di sarungkan, dan pihak Quraisy tidak boleh menghalangi dengan cara apapun, (2) gencatan senjata diberlakukan selama sepuluh tahun. Tidak tindakan saling menyerang di antara kedua belah pihak selama kurun waktu tersebut, (3) kabilah-kabilah yang berada di luar perjanjian itu dibolehkan menjalin persekutuan dengan salah satu pihak yang terlibat dalam perjanjian tersebut, dan menjadi bagian dari sekutunya. Sehingga penyerangan terhadap kabilah-kabilah yang menjalin persekutuan, dianggap penyerangan terhadap sekutunya yang terlibat dalam perjanjian, (4) Jika ada orang dari pihak musyrikin Quraisy yang datang kepada Muhammad tanpa seizin walinya maka ia harus dikembalikan. Sebaliknya kalau ada pengikut Muhammad yang membelot kepada musyrikin Quraisy, maka ia tidak akan dikembalikan. Safiyyurahman al-Mubarakfuri, Al-Rahiq al-Makhtum, h. 444-445. Lihat juga: Hafiz bin Muhammad Abdullah al-Hakami, Marwiyyat Gazwah al-Hudaibiyah, 166.

${ }^{17}$ Safiyyurahman al-Mubarakfuri, Al-Rahiq al-Makhtum, 484.
} 
negaranya. ${ }^{18}$ Juga berbeda dengan perspektif rasionalisme, yang memandang bahwa kepatuhan terhadap hukum internasional dilandasi oleh motif utilitarian, hukum internasional akan dipatuhi jika keuntungan bersama diperoleh dari hukum tersebut. ${ }^{19}$

Secara ideografis, kaum muslimin adalah kaum yang mulia dan menjunjung tinggi kejujuran, serta senantiasa taat kepada Allah dan rasul-Nya. Secara purposif yang diinginkan oleh kaum muslimin adalah mendakwahkan agama tauhid kepada seluruh manusia. Oleh karena itu, kebebasan beragama harus terwujud. Secara etis ada kesesuaian antara aturan Islam dengan norma-norma bersama (Costumary Law) karena Islam memerintahkan umatnya untuk memenuhi janji dan melarang menggunakan perjanjian sebagai alat menipu. Di sisi lain, keharusan menaati perjanjian merupakan norma hubungan internasional yang berlaku. Secara instrumental, perjanjian damai diperlukan untuk tujuan mendakwahkan Islam. ${ }^{20}$

\section{Model Komunikasi Internasional Perjanjian Hudaibiyah}

Pakar komunikasi biasanya merancang model komunikasi dengan menggunakan rangkaian blok, segi empat, lingkaran, panah, garis, spiral, dan sebagainya untuk mengidentifikasi komponen, variabel, atau kekuatan-kekuatan yang membentuk komunikasi. Kemudian meyarankan atau menggambarkan hubungan di antara komponen-komponen tersebut. ${ }^{21}$

Untuk mempermudah pemodelan komunikasi, sangat perlu memahami terlebih dahulu taksonomi model Hanneman-McEwen di bawah ini. Taksonomi ini berupa grafik yang melukiskan derajat abstraksi yang berlainan.

\footnotetext{
${ }^{18} \mathrm{~J}$. Martin Rochester, Between Peril and Promise: The Politics of International Law (Whasington D.C.: CQ Press, 2006), 18.

19J. Martin Rochester, Between Peril and Promise, 44.

${ }^{20}$ Sidiq Ahmadi, "Perianjian Hudaibiyah", 84.

${ }^{21}$ Ralph Webb Jr., Interpersone/ Speech Communication: Principles and Practices (New Jersey: Prentice-Hall, 1975), h. 14; dikutip dalam Deddy Mulyana, I/mu Komunikasi, 133.
} 


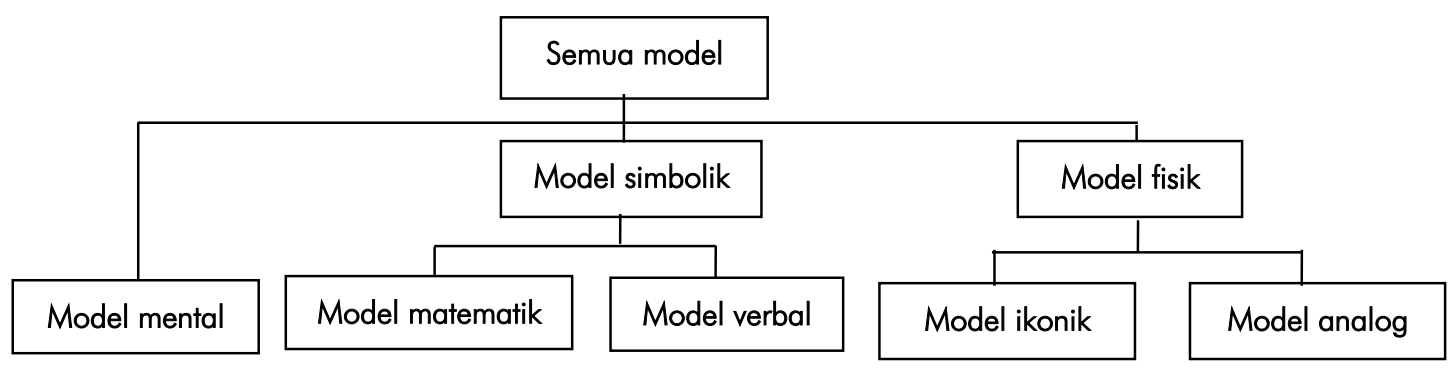

Gambar 1: Bentuk-bentuk model Hanneman-McEwen ${ }^{22}$

Pada umumnya model yang baik biasanya telah melewati banyak tahapan ujian, dalam waktu yang mungkin panjang. Oleh karena itu suatu model dapat diperbaiki dari waktu ke waktu menyesuaikan dengan data-data temuan di lapangan. ${ }^{23}$

Irwin DJ. Bross menggambarkan interaksi model dengan data-data temuan lapangan seperti berikut ini:

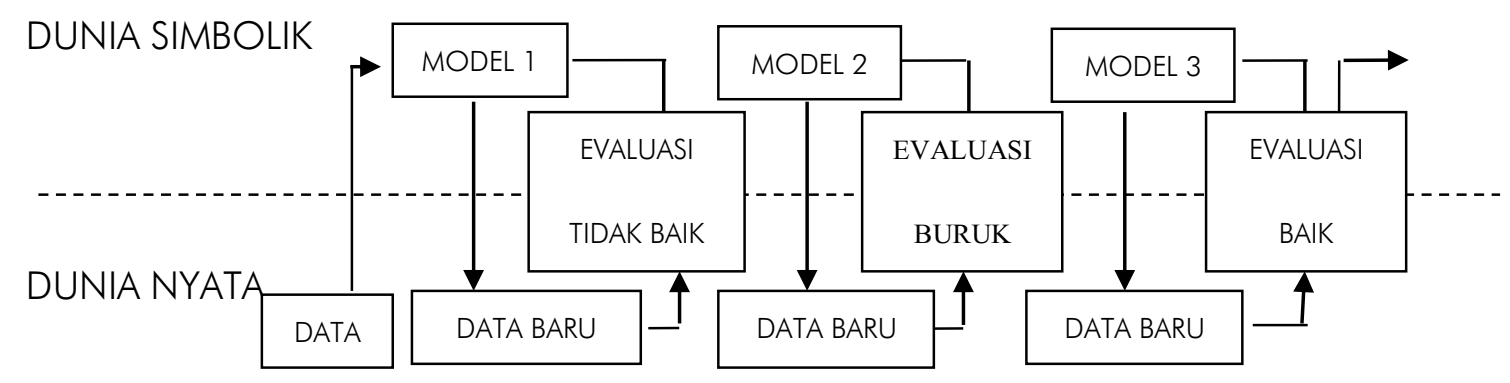

Gambar 2: Interaksi antara model dan data ${ }^{24}$

Model komunikasi internasional Perjanjian Hudaibiyah dalam kajian ini selain didasarkan pada kemanfaatannya dalam menjaring data penelitian, juga berlandaskan pada pendekatan dan perspektif komunikasi internasional, fungsi komunikasi, kepentingan dalam komunikasi internasional, serta bentuk-bentuk komunikasi internasional. Komunikasi internasional sangat menekankan pada pesan yang bermuatan kebijakan dan kepentingan suatu negara terhadap negara lain sebagai realitas politik yang terkait dengan masalah ekonomi, politik, pertahanan, dan lain-lain.

\footnotetext{
${ }^{22}$ Mary B. Cassata dan Molefi K. Asante, Mass Communication, 64.

${ }^{23}$ Deddy Mulyana, Ilmu Komunikasi, 136.

${ }^{24}$ Irwin DJ. Bross, "Models" dalam James H. Campbell dan Hal W. Hepler, eds, Dimension in Communication, 23.
} 
Perjanjian Hudaibiyah dalam tinjauan komunikasi internasional, diaplikasikan dalam tiga pendekatan dominan, yaitu: pendekatan idealistik-humanistik, kepengikutan politik baru (political proselytization), dan kekuatan politik. Dalam prakteknya di lapangan, komunikasi internasional Perjanjian Hudaibiyah menggunakan perspektif diplomatik.

Pendekatan idealistik-humanistik dalam Perjanjian Hudaibiyah dilakukan khususnya untuk menjaga stabilitas kawasan Jazirah Arab. Sehingga setiap pihak yang terlibat secara langsung maupun tidak langsung dalam perianjian tersebut, berusaha bersungguh-sungguh memelihara kelangsungan komunikasi internasional. Setiap persoalan regional harus dapat diatasi melalui komunikasi yang efektif hingga berhasil melahirkan penyelesaian. Sehingga pada ranah ini komunikasi internasional Perjanjian Hudaibiyah dengan pendekatan idealistik menjadi sangat penting dan diperlukan.

Dari uraian di atas, model komunikasi internasional Perjanjian Hudaibiyah dapat digambarkan sebagai berikut:

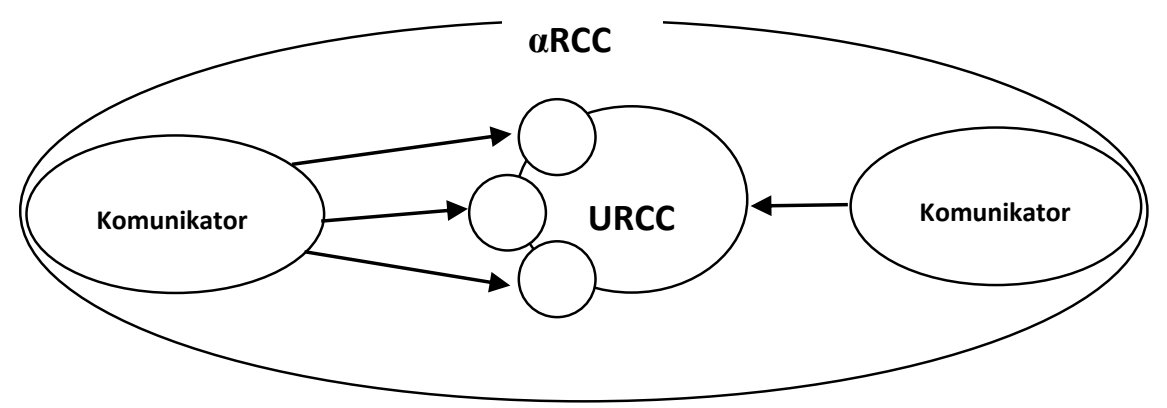

Gambar 3: Model komunikasi internasional Perjanjian Hudaibiyah Model komunikasi internasional Perjanjian Hudaibiyah merupakan model komunikasi diagramatik sirkuler yang memperlihatkan komunikasi berlangsung dalam konteks yang mempengaruhi komunikasi itu sendiri. Konteks tersebut adalah faktor-faktor di luar orang-orang yang berkomunikasi, yang terdiri dari aspek fisik, psikologis, sosial, dan waktu.

Komunikasi internasional Perjanjian Hudaibiyah juga tergolong komunikasi antarbudaya, berupa komunikasi tatap-muka diadik, sehingga pengirim, dalam hal ini adalah Rasulullah saw. dan Suhail, 
sekaligus bertindak sebagai penerima yang melakukan encoding dan decoding pesan. Encoding dan decoding merupakan proses interaktif yang dipengaruhi oleh filter-filter konseptual yang dikategorikan menjadi faktor-faktor budaya, sosiobudaya, psikobudaya, dan faktor lingkungan. Filter tersebut menjadi mekanisme yang membatasi jumlah alternatif yang memungkinkan untuk dipilih ketika melakukan encoding dan decoding.

Perspektif interaksionalisme simbolik juga mendapat ruang dalam model komunikasi internasional Perjanjian Hudaibiyah. Tiga premis Blumer yang dikemukakan oleh Fisher dan menjadi dasar model komunikasi interaksional dalam Perjanjian Hudaibiyah dapat dilihat dalam: (1) makna yang diberikan oleh kedua belah pihak, (2) hubungan makna dengan interaksi sosial lingkungannya, (3) upaya mempertahankan makna yang telah diciptakan, khususnya setelah klausul Perianjian Hudaibiyah disepakati.

Di luar aspek-aspek yang disebutkan di atas, pesan (message/konten komunikasi) dari Rasulullah saw. bekerja menurut hukum medan magnet. Penulis menyebutnya dengan the Unique of Rasulullah Communication Content/URCC (khasais al-maddat al-ittisaliah al-Rasul). ${ }^{25}$ Dalam URCC prinsip hukum medan magnet ini bekerja dengan cara menarik konten komunikasi lawannya yang berupa sosio-psikobudaya yang berbeda dengannya, kemudian memantul dan menyebarkan kembali konten komunikasi lawannya yang mempunyai kesamaan dengannya.

URCC mampu menarik dan menolak konten komunikasi lawan karena precision rightness-nya (al-'azimat ma'anih wa al-jalilat ausafih) yang lebih besar dari konten komunikasi lawannya. ${ }^{26}$ Precision rightness

\footnotetext{
${ }^{25}$ Hukum Medan magnet adalah proses tertariknya benda-benda logam di sekitar Medan magnetik karena adanya gaya tarik yang berada pada kutub selatan magnet dan daya tolak yang berada pada kutub utara magnet. David C. Jiles, Introduction to Magnetism and Magnetic Materials, 2 ed. (Florida: CRC Press, 1998), h. 3. Lihat juga: M. Gerloch, Magnetism and Ligand-field Analysis (Cambridge: Cambridge University Press, 1983), 110.

${ }^{26}$ Lihat: Abdurrahman bin Nasir al-Sa'di, Taisir al-Karim al-Rahman fi Tafsir Kalam alMannan (Cet.II; KSA: Dar Ibn al-Jauzi, 1426 H). Teri. Muhamad lqbal dkk., Tafsir alQur'an, Jilid 7(Cet. III; Jakarta: Darul Haq, 2013), 427.
} 
URCC ini dinyatakan oleh Allah swt. dalam firman-Nya QS alMuzammil/73: 5: sebagai "Qaulan Saqilan" (perkataan yang berat). ${ }^{27}$

Konten komunikasi lawan yang ditarik oleh URCC mengalami adhes ${ }^{28}$ sesuai prinsip URCC sebelum disebarkan kembali. Kecepatan dan arah penyebaranya hasil adhesi URCC bergerak menurut konstanta Rasulullah Communication Content Speed (aRCC). aRCC senantiasa menyesuaikan diri dengan waktu dan lingkungan komunikasi tersebut berlangsung. aRCC bisa berlangsung cepat, bisa juga dalam waktu yang panjang. aRCC dinyatakan dalam hadis yang diriyawatkan Imam Ahmad dari Tamim al-Dari no. 16957:

"Sungguh urusan ini akan sampai kepada apa saja yang dilalui siang dan malam, Allah tidak menyisakan satu pun gedung dan gubuk, kecuali Allah akan memasukkan agama ini ke dalamnya dengan kemuliaan orang yang mulia atau dengan kehinaan orang yang hina, kemuliaan yang dengannya Allah muliakan Islam dan kehinaan yang dengannya Allah hinakan kekafiran" ${ }^{29}$

Selanjutnya dalam penyebaran hasil adhesi, ada kemungkinan akan mengalami gangguan baik gangguan teknis maupun gangguan semantik seperti dalam model komunikasi transaksionalnya. Gangguan teknis adalah faktor yang menyebabkan si penerima menerima informasi atau rangsangan, bukan yang semestinya. Dan gangguan semantik adalah pemberian makna yang berada atas lambang yang disampaikan pengirim berbeda dari yang semestinya.

Untuk mengatasi gangguan-gangguan tersebut di atas, penulis mengajukan postulat "tajdid (pembaharuan)" berdasarkan hadits yang diriwayatkan oleh Abu Daud, dari Abu Hurairah ra.:

\footnotetext{
${ }^{27}$ Kementerian Agama RI, Al-Qur'an dan Terjemahannya (Cet. I; Bandung: Cordoba Internasional Indonesia, 2015), 574.

${ }^{28}$ Adhesi adalah yaitu proses penyesuaian diri dari kepercayaan lama kepada kepercayaan baru (Islam) Ahamd M. Sewang "Penerapan Syariat Islam di Sulawesi Selatan", Makalah disampaikan dalam Kongres II Umat Islam Sulawesi Selatan di Asrama Haji Sudiang Makassar, (Makassar, 29-31 Desember 2001), 2.

${ }^{29}$ Abdullah bin Abdul Muhsin al-Turki, Mausu'ah al-Hadisah: Musnad Ahmad bin Hanbal Tahqiq: Syua'aib al-Arnaut, Juz 28 (Cet. I; Beirut: al-Mu'assasat al-Risalah, 1419 H/1999 M), 155.
} 
"Sesungguhnya Allah mengutus kepada umat ini setiap seratus tahun ${ }^{30}$ orang (yang) memperbaharui agama mereka". ${ }^{31}$

Jika postulat di atas dikaitkan dengan Islam kekinian di Indonesia, penulis bisa menyoroti slogan yang mulai ramai disebarkan beberapa waktu lalu, yang disebut dengan Islam Nusantara. Berdasarkan postulat di atas, Islam Nusantara yang diklaim sebagai bentuk keberislaman orang Indonesia yang inklusif, dan hendak dipopulerkan atau didakwahkan ke dunia internasional, merupakan sebuah klaim yang prematur. Klaim bahwa Islam Nusantara sebagai bentuk keberislaman moderat, tawassut, dan toleran dengan segala bentuk ideologi dan faham-faham lain, kalau dilihat dari sisi URCC maupun aRCC, keberislaman orang Indonesia sejak agama Islam masuk sebagai bagian dari sistem-sistem sosial masyarakat Indonesia sampai hari ini, sebenarnya masih merupakan bagian dari proses komunikasi, khususnya proses adhesi yang masih terus berlangsung.

Proses komunikasi tersebut akan terus berlangsung sampai orisinalitas URCC kembali kepada bentuknya semula, yang bebas dan terjaga dari segala bentuk inhiraf (penyimpangan) maknawiyah maupun maddiyah. Bebas dan terjaga dari penyimpangan substantif atau prinsipil. Sebagai sebuah proses, hal ini akan terus bergerak, bermetamorfosis sampai pada finalisasi, dengan diterapkannya firman Allah swt. dalam QS alAhzab/33: 36.

Keberislaman yang benar dan orisinil adalah ketika sistem-sistem alQuran dan al-Sunnah menjadi satu-satunya sistem yang melingkupi sistem-sistem sosial yang ada.

\footnotetext{
${ }^{30}$ Setiap seratus tahun, aRCC mengalamai renewal atau reorientasi. Dengan demikian, untuk melihat hasil dari proses komunikasi yang dilakukan oleh Rasulullah saw., khusunya pada Perjanjian Hudaibiyah, bisa dilihat dari efek komunikasi yang terjadi setelah penandatanganan perjanian tersebut, sampai masa periodik seratus tahunan berikutnya.

${ }^{31}$ Sulaiman bin al-Asy'as al-Sajastani, Sahih Sunan Abi Dawud, Jilid 3 (Cet.Il; Ryad: Al-Maktabah al-Ma'arif, 1421 H/2000 M), h.23. Hadis| ini disahihkan oleh Al-Sakhawi, lihat: Muhammad Abdurrahman al-Sakhawi, Al-Maqsid al-Hasanah fi Bayani Kaśir min alAhadis al-Musytahirah 'ala al-Alsinah, Tahqiq: Muhammad Usman al-Khait (Cet. I; Beirut: Dar al-Kitab al-'Arabi, 1405 H/1975 M), 203.
} 


\section{Dakwah Islam di Kawasan ASEAN}

Pembahasan dakwah di kawasan ASEAN tidak dapat dilepaskan dari proses masuk, tumbuh, dan berkembangnya Islam di Asia Tenggara. Awal persentuhan masyarakat Asia Tenggara dengan Islam terjadi pada akhir abad I H atau akhir abad VII M. ${ }^{32}$ Dengan demikian, Islam sudah menjadi agama sebagian masyarakat Asia Tenggara, jauh sebelum kedatangan agama Kristen yang dibawa Portugis saat mengalahkan kesultanan Malaka tahun 1511, pendudukan Spanyol atas Filipina tahun 1565, dan Belanda tahun 1602. ${ }^{33}$

Interaksi yang terjadi antara pedagang muslim Arab dengan penduduk lokal di setiap pelabuhan yang disinggahi sepanjang jalur perdagangan itu mendorong terbentuknya koloni-koloni muslim. Hubungan yang semakin erat antara koloni-koloni muslim yang di wilayah-wilayah perlintasan perdagangan itu, juga semakin menguatkan perkembangan Islam. Mulai dari kerajaan Champa, ${ }^{34}$ Pagan (Bagan) dan Arakan (Myanmar), ${ }^{35}$ kesultanan Peureulak, ${ }^{36}$ Pattani Darussalam, ${ }^{37}$ Samudera Pasai, ${ }^{38}$ dan kesultanan Malaka. ${ }^{39}$ Ketika Malaka dikuasai oleh Portugis tahun 1511, perkembangan Islam semakin masif dan terus melebar ke Johor, Aceh Darussalam, ${ }^{40}$ Palembang, Banten, Demak dan

\footnotetext{
${ }^{32}$ Daud Ali M., Hukum Islam Pengantar: Hukum dan Tata Hukum Islam di Indonesia (Jakarta: RajaGrafindo Persada, 1995), 209.

${ }^{33}$ Sudir Koadhi, "Pengaruh Peradaban Islam di Dunia Barat", Makalah tidak diterbitkan (Makassar, PPS, 2015), 2.

${ }^{34} \mathrm{https}$ ://www.republika.co.id/berita/dunia-islam/islam-nusantara/17/04/09/ oo4x5g3 13 -islam-di-era-kerajaan-campa (diakses 19 Juni 2018)

${ }^{35}$ Moshe Yegar, between integration and secession: the Muslim communities of the southern Philippines, Southern Thailand, and western Burma/Myanmar (Lanham, Md.: Lexington Books, 2002), h. 19. Lihat juga: "History of Arrival of Islam in Burma/ Myanmar," http://en.wikipedia.org/wiki/Islam_in_Burma (diakses 21 Juni 2018).

${ }^{36}$ A. Hasyimi, Sejarah Masuk dan Berkembangnya Islam di Indonesia (Bandung: Alma'arif, 1993), 144.

${ }^{37}$ Paulus Rudolf Yulianto, "Integrasi Muslim Patani: Reidentitas Sosial atas Dominasi Nasional Thailand", dalam www.digilib.vin-suka.ac.id (Yogyakarta: UIN Sunan Kalijaga, t.th), 5.

${ }^{38}$ Daud Ali M., Hukum Islam Pengantar, h. 209. Lihat juga: Saifuddin Zuhri, Sejarah Kebangkitan Islam dan Perkembangannya di Indonesia (Bandung: Alma'arif, 1981), 197

${ }^{39}$ M.C. Ricklefs, Sejarah Indonesia Modern (Yogyakarta: UGM Press, 1998), 28-30.

${ }^{40}$ Darmawijaya, Kesultanan Islam Nusantara (Cet. I; Jakarta: Pustaka Al-Kautsar, 2010), 4.
} 
Cirebon. ${ }^{41}$ Dari ketiga kesultanan terakhir ini, Islam tersebar keseluruh penjuru pulau Jawa melalui dakwah Wali Songo. ${ }^{42}$ Dari tanah Jawa Islam menyebar ke kepulauan Maluku dan membentuk kekuasaan politik melalui kesultanan Ternate, Tidore, Bacan, dan Jailolo. ${ }^{43}$ Juga, dari tanah Jawa Islam masuk ke Kalimantan bagian Selatan. Pada bagian, Islam masuk ke Brunei Darussalam, Kalimantan bagian Barat, dan terus menyebar ke kepulauan Zulu, Mindanau, dan Luzon (Filipina) melalui Johor. ${ }^{44}$ Dan dari tanah Minang, melalui Dato' Tellue (tiga Datuk) Islam membentuk kekuasaan politik di kesultanan Gowa-Tallo (Makassar) sebelum menyebar keseluruh pulau Sulawesi, ${ }^{45}$ Nusa Tenggara, ${ }^{46}$ dan Kalimantan bagian Timur. ${ }^{47}$

Masuknya bangsa kolonial ke Asia Tenggara dengan semboyang Gospel, Glory, and Gold yang merupakan usaha menyalakan kembali sisa-sisa bara perang salib yang berkobar pada abad V-VII, berhadapan via a vis dengan eksistensi ekonomi dan kekuasaan politik kaum muslimin. Akibatnya kaum muslimin mengalami instabilitasi ekonomi dan disintegrasi politik yang terus berlangsung pasca kolonialisasi hingga krisis keuangan melanda Asia Tenggara tahun 1998. Krisis keuangan ini menyadarkan banyak pihak akan kelemahan ekonomi neoliberalisme yang merupakan perpanjangan tangan kolonialisme. Dan bagi kaum muslimin, menguatkan kembali keinginan untuk menegakkan izzah-nya melalui ekonomi dan politik.

\footnotetext{
${ }^{41}$ Darmawijaya, Kesultanan Islam Nusantara, 10-40

${ }^{42}$ Mohammad Jamil, Melaka Pusat Penyebaran Islam di Nusantara (Kualalumpur: Nurin Enterprise, 1994), 70.

${ }^{43}$ Mundzirin dkk, Sejaran Peradaban Islam di Indonesia (Yogyakarta: Pustaka Pinus, 2006), 105.

${ }^{44}$ Cesar Adib Majul, Dinamika Islam Filipina (Jakarta: LP3S, 1991), 8

${ }^{45}$ Darmawijaya, Kesultanan Islam Nusantara, 97.

${ }^{46}$ Saifuddin Zuhri, Sejarah Kebangkitan Islam dan Perkembangannya di Indonesia (Bandung: Alma'arif, 1981), 424.

${ }^{47}$ Saifuddin Zuhri, Sejarah Kebangkitan Islam dan Perkembangannya di Indonesia, 424.
} 


\section{Metode Dakwah Era Masyarakat Ekonomi ASEAN (MEA)}

Penyebaran Islam era MEA akan mengikuti pola masuknya Islam ke Asia Tenggara, yaitu melalui jalur perdagangan dan jalur politik dengan beberapa variasi yang dipengaruhi oleh situasi politik, sosial budaya, dan keamanan Asia Tenggara pada era tersebut. Oleh sebab itu metode dakwah pada era MEA bertumpu pada dua unsur zimam al-hayat (politik dan ekonomi) tersebut.

Meminjam ungkapan imam Malik, 48 "la yasluhu akhir hazih alummah illa ma aslaha awwaluha" (tidak ada yang dapat memperbaiki akhir umat ini, kecuali apa yang telah memperbaiki generasi awalnya), ${ }^{49}$ dan pendapat Immanuel Kant dalam pendekatan kaum liberalis dalam hubungan internasional, yang menyatakan dengan semangat berdagang (the spirit of commerce), perdamaian antara negara-negara Asia Tenggara akan semakin kuat dengan kerja sama ekonomi dan interdependensi. Perkataan imam Malik dan pendapat Kant ini, masih sangat relevan sebagai metode dakwah di era MEA.

Berangkat dari hal di atas, maka metode dakwah era MEA adalah:

1. Metode Dakwah Ekonomi, yang dilaksanakan dalam bentuk: (a) dakwah ekonomi pembinaan, yaitu pembinaan keislaman dan ekonomi Islam terhadap pelaku ekonomi dari kaum muslimin, (b) dakwah ekonomi pemberdayaan, yaitu advokasi dan bantuan modal oleh pemodal kaum muslimin dan lembaga keuangan Islam untuk meningkatkan daya saing pelaku ekonomi dari kaum muslimin menghadapi pasar bebas MEA, (c) dakwah ekonomi transaksional, yaitu dakwah yang dilakukan oleh para pelaku ekonomi Islam mengasumsikan bahwa mad'u mengalami

\footnotetext{
${ }^{48} \mathrm{Abu}$ Abdillah Malik bin Anas bin Malik bin Abi Amir żi Asbah, lahir di Madinah alNabawiyyah tahun $93 \mathrm{H}$, tabi'in, mu'allif kitab al-Muwatta, mu'assis mazhab Maliki, wafat di Madinah al-Nabawiyyah tahun $179 \mathrm{H}$.

${ }^{49}$ Diriwayatkan oleh Qadi Ismail bin Ishak al-Jahdami al-Maliki (w. 282 H), Al-Mabsut; dikutip dalam: Al-Qadi Abu al-Fadl lyad bin Musa bin lyad al-Andalusi, Al-Syifa bi al-Ta'rif Huquq al-Mustafa (Kairo: Dar al-Hadis, t.th), h. 325. Lihat juga: Taqiuddin Abu al-Abbas Ahmad bin Abdul Halim Ibnu Taimiyyah, lada al-Sirat al-Mustaqim (Riyad: Maktabah alRusyd, t.th), 763.
} 
perubahan sebagai hasil dari terpaan pesan (konten) dakwah yang diterimanya. Dengan demikian, dakwah ekonomi transaksional bersifat irreversible artinya mad'u tidak dapat berada dalam posisi semula, sebelum diterpa pesan dakwah yang dikirim oleh dai, secara verbal maupun nonverbal yang disengaja ataupun tidak disengaja. ${ }^{50}$ Salah satu strategi pemasaran dakwah dalam mengembangkan dakwah ekonomi transaksional adalah melalui konsep Awareness, Interest, Desire, Decision, dan Action (AIDDA), seperti padagambar berikut ini:

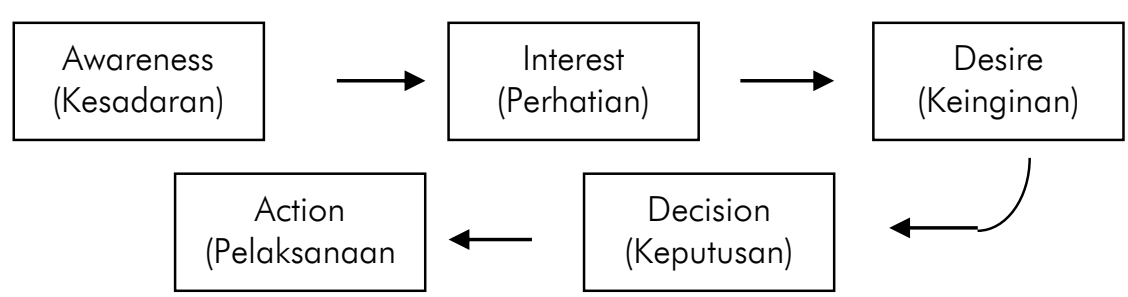

Gambar 4: Model pemasaran dakwah AIDDA. ${ }^{51}$

(d) dakwah ekonomi interaksionalisme simbolik, yaitu upaya membentuk objek sosial baru yang perlu dimaknai bersama antara dai (pelaku ekonomi dari kaum muslimin) dengan mad'u yang non muslim. Objek sosial tersebut adalah syariat Islam yang melekat pada diri dai dan dipraktekkannya dalam transaksi ekonomi dan dalam kehidupannya sehari-hari, dan menjadi role-model bagi

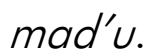

2. Metode Dakwah Politik dilaksanakan melalui jalur diplomasi. Pendekaatan idealistik-humanistik dalam hubungan internasional di Asia Tenggara, cukup berkonstribusi menjaga stabilitas kawasan Asia Tenggara. Dengan pendekatan ini, setiap negara dalam kawasan tersebut terus bersungguh-sungguh memelihara

${ }^{50}$ Saundra Hybels dan Richard L. Weaver II, Speech/Communication. Ed.II (New York: D. Van Nostrand, 1979), 5.

${ }^{51}$ Direvisi dari: Hafied Cangara, Perencanaan dan Strategi Komunikasi. Ed. Revisi (Cet. II; Jakarta: RajaGrafindo Persada, 2014), 83. 
kelangsungan komunikasi internasional melalui perjanjianperjanjian dan kesepakatan damai. Dengan adanya perjanjian dan kesepakatan damai itu, aktifitas internasional dapat berjalan dengan baik, termasuk dakwah yang dilakukan kaum muslimin. Akan tetapi pada sisi political proselytization, dan kekuatan politik Islam di Asia Tenggara senantiasa mendapat hambatan dari pemegang otoritas, terutama di negara-negara yang berpenduduk minoritas kaum muslimin. Dakwah politik melalui jalur diplomasi sangat dibutuhkan guna mendukung dan memayungi dakwah sosial internasional yang telah dilakukan oleh berbagai lembaga dakwah internasional dan individu di kawasan Asia Tenggara. Dakwah politik melalui jalur diplomasi adalah kegiatan dakwah yang dilakukan oleh pemerintah atau negara kepada pemerintah atau negara lain melalui saluran diplomatik, secara interpersonal. Dakwah politik melalui jalur diplomatik merupakan kegiatan atau upaya untuk membina rasa saling percaya atau memperteguh keyakinan terhadap suatu gagasan. Dengan menggunakan saluran-saluran diplomatik, dakwah politik dilakukan untuk memperluas pengaruh, meningkatkan komitmen dan solidaritas, menanggulangi perbedaan pendapat dan salah paham, sampai menghindari pertentangan dalam masalah tujuan dan kepentingan yang dikehendaki suatu negara, mengembangkan kerja sama, baik dalam hubungan bilateral maupun multilateral, memperkuat posisi tawar (bargaining position) serta meningkatkan citra dan reputasi suatu negara, melalui first track, second track, dan multitrack diplomacy.

\section{Kesimpulan}

Diskursus metode dakwah dalam bingkai regionalisme Asia Tenggara bukanlah persoalan yang murni langsung bersentuhan dengan nalar kehidupan mad'u, seperti pemenuhan unsur-unsur pokok dalam kehidupan (zimam al-hayah). Konteks mengembalikan izzah kaum muslimin melintas ke era Masyarakat Ekonomi ASEAN (MEA) yang mulai 
diberlakukan secara bertahap sejak 2015 dengan motto one vision, one identity and one community, menjadi embrio lahirnya konstruksi model komunikasi internasional Perjanjian Hudaibiyah untuk pertama kali. Gagasan utama dari konstruksi model komunikasi internasional Perjanjian Hudaibiyah ini yang merupakan representasi dari keniscayaan syumuliyyat al-Islam adalah wus'ah maidan al-da'wah (medan dakwah yang mengalami perluasan). Konstruksi model komunikasi internasional Perjanjian Hudaibiyah sangat relevan untuk dikedepankan sebagai piranti utama dalam merumuskan metode dakwah era MEA 


\section{Daftar Pustaka}

Abdat, Abdul Hakim. Politik Islam: Mendulang Faidah dari Kisah Perjanjian Hudaibiyah, Ed. Ibnu Saini Muhammad Musa. Cet. I; Jakarta: Maktabah Mu'awiyah bin Abi Sufyan, 2013

Ahmadi, Sidiq. "Perjanjian Hudaibiyah sebagai Model Kepatuhan terhadap Perianjian Internasional dalam Perspektif Islam", Tesis. Yogyakarta: Fak. Ilmu Sosial dan IImu Politik Universitas Gadjah Mada, 2014

Al-Andalusi, Al-Qadi Abu al-Fadl lyad bin Musa bin lyad. Al-Syifa bi alTa'rif Huquq al-Mustafa. Kairo: Dar al-Hadis, t.th.

Al-Hakami, Hafiz bin Muhammad Abdullah. Marwiyyat Gazwah a/Hudaibiyah. Madinah al-Munawwarah: Ihya' al-Turas al-Islami, t.th.

Al-Mubarakfuri, Safiyyurahman. Al-Rahiq al-Makhtum, Pengantar: Muhammad Ali al-Harakan, terj. Kathur Suhardi, Sirah Nabawiyah. Cet. II; Jakarta: Pustaka Al-Kautsar, 2002.

Al-Salabi, Ali Muhammad. Al-Daulah al-'Usmaniyyah: 'Awamil alNuhud wa Asbab al-Suqut. Teri. Samson Rahman, Bangkit dan Runtuhnya Khilafah Utsmaniyah. Cet. IV; Jakarta: Pustaka AlKautsar, 2011.

Al-Sa'di, Abdurrahman bin Nasir. Taisir al-Karim al-Rahman fi Tafsir Kalam al-Mannan. Cet.II; KSA: Dar Ibn al-Jauzi, 1426 H. Teri. Muhamad lqbal dkk., Tafsir al-Qur'an, Jilid 7. Cet. III; Jakarta: Darul Haq, 2013.

Al-Sajastani, Sulaiman bin al-Asy'as. Sahih Sunan Abi Dawud, Jilid 3. Cet.Il; Ryad: Al-Maktabah al-Ma'arif, 1421 H/2000 M.

Al-Sakhawi, Muhammad Abdurrahman. Al-Maqsid al-Hasanah fi Bayani Kasir min al-Ahadis al-Musytahirah 'ala al-Alsinah, Tahqiq: Muhammad Usman al-Khait. Cet. I; Beirut: Dar al-Kitab al-'Arabi, $1405 \mathrm{H} / 1975 \mathrm{M}$. 
Al-Turki, Abdullah bin Abdul Muhsin. Mausu'ah al-Hadisah: Musnad Ahmad bin Hanbal Tahqiq: Syua'aib al-Arnaut, Juz 28. Cet. I; Beirut: al-Mu'assasat al-Risalah, 1419 H/1999 M Al-Qurtubi, Abu 'Abdillah Muhammad bin Ahmad Abu Bakr Syams alDin. Al-Jami' li Ahkam al-Qur'an. Tahqiq: Ahmad Barduni dan Ibrahim Atfis, Juz 8. Cet. II; Kairo: Dar al-Kutub al-Misriyyah, 1964 Bross, Irwin DJ. "Models" dalam James H. Campbell dan Hal W. Hepler, eds, Dimension in Communication: Readings. California: Wadsworth, 1965

Cangara, Hafied. Perencanaan dan Strategi Komunikasi. Ed. Revisi. Cet. II; Jakarta: RajaGrafindo Persada, 2014 Cassata, Mary B. dan Molefi K. Asante, Mass Communication: Principles and Practices. New York: Macmillan, 1979

Darmawijaya, Kesultanan Islam Nusantara. Cet. I; Jakarta: Pustaka AlKautsar, 2010.

Fisher, B. Aubrey. Communication Theories. Teri. Soejono Trimo, Teori-teori Komunikasi. Bandung: Remaja Rosdakarya, 1986.

Gerloch, M. Magnetism and Ligand-field Analysis. Cambridge:

Cambridge University Press, 1983

Hasyimi, A. Sejarah Masuk dan Berkembangnya Islam di Indonesia.

Bandung: Alma'arif, 1993

Henderson, Conway W. International Relations: Conflict and Cooperation at the Turn of 21 st Century. New York: McGraw-Hill International, 1998

http://whc.unesco.org/en/events/1378

https://id. wikipedia.org/

https://www.republika.co.id/berita/dunia-islam/islam-

nusantara/17/04/09/ oo4×5g3 13 -islam-di-era-kerajaan-campa https://www.southeastasianarchaeology.com/tag/maritime-silk-route/ Hybels, Saundra dan Richard L. Weaver II, Speech/Communication. Ed.II. New York: D. Van Nostrand, 1979

Ibn Hisyam, Abu Muhammad Abd al-Malik. Al-Sirah al-Nabawiyyah, Juz 3. Cet. II; Mesir: Mat|ba'ah al-Halabi wa Auladuh, $1375 \mathrm{H}$. 
Ibnu Taimiyyah, Taqiuddin Abu al-Abbas Ahmad bin Abdul Halim. Iqda al-Sirat al-Mustaqim. Riyad: Maktabah al-Rusyd, t.th.

Jamil, Mohammad. Melaka Pusat Penyebaran Islam di Nusantara. Kualalumpur: Nurin Enterprise, 1994

Jiles, David C. Introduction to Magnetism and Magnetic Materials, 2 ed. Florida: CRC Press, 1998

Kementerian Agama RI, Al-Qur'an dan Terjemahnya. Cet. I; Bandung: Cordoba Internasional Indonesia, 2015

Koadhi, Sudir. "Pengaruh Peradaban Islam di Dunia Barat", Makalah tidak diterbitkan. Makassar, PPS, 2015

M., Daud Ali. Hukum Islam Pengantar: Hukum dan Tata Hukum Islam di Indonesia. Jakarta: RajaGrafindo Persada, 1995

Majul, Cesar Adib. Dinaniika Islam Filipina. Jakarta: LP3S, 1991

Mulyana, Deddy. Ilmu Komunikasi: Suatu Pengantar. Cet.XIX; Bandung: Remaja Rosdakarya, 2015

Mundzirin dkk, Sejarah Peradaban Islam di Indonesia. Yogyakarta: Pustaka Pinus, 2006

Niemeijer, Hendrik E. "Dividing the Islands: The Dutch Spice Monopoly and Religious Change in 17th Century Maluku" dalam The Propagation of Islam in the Indonesian-Malay Archipelago. Translaetd by H.M. Froger. Kuala Lumpur: Malaysian Sosiological Research Institute, 2001

Perwita, Anak Agung Banyu dan Yanyan Mochamad Yani, Pengantar IImu Hubungan Internasional. Cet. IV; Bandung: Remaja Rosdakarya, 2014

Reid, Anthony. "Isalmization and Christianization in Southeast Asia: The Critical Phase, 1550-1650" dalam Southeast Asia in the Early Modern Era: Trade, Power, and Belief, ed. Anthony Reid. Ithaca/London: Cornell University Press, 1993

Ricklefs, M.C. Sejarah Indonesia Modern. Yogyakarta: UGM Press, 1998

Rochester, J. Martin. Between Peril and Promise: The Politics of International Law. Whasington D.C.: CQ Press, 2006 
Ross, Raymond S. Speech Communication: Fundamentals and Practice. Edisi VI. New Jersey: Englewood Cliffs, 1983.

Saverin, Werner J. dan James W. Tankard Jr. Communication Theories: Origins, Methods, and Uses in the Mass Media, Edisi III. New York: Longman, 1992

Sewang, Ahamd M. "Penerapan Syariat Islam di Sulawesi Selatan", Makalah disampaikan dalam Kongres II Umat Islam Sulawesi Selatan di Asrama Haji Sudiang Makassar. Makassar, 29-31 Desember 2001

Shoelhi, Mohammad. Diplomasi: Praktik komunikasi Internasional. Cet. I; Bandung: Simbiosa Rekatama Media, 2011 Komunikasi Internasional Perspektif Jurnalistik. Cet. II; Bandung: Simbiosa Rekatama Media, 2014

Webb Jr., Ralph. Interpersone/ Speech Communication: Principles and Practices. New Jersey: Prentice-Hall, 1975

Yegar, Moshe. Between integration and secession: the Muslim communities of the southern Philippines, Southern Thailand, and western Burma/Myanmar. Lanham, Md.: Lexington Books, 2002.

Yulianto, Paulus Rudolf. "Integrasi Muslim Patani: Reidentitas Sosial atas Dominasi Nasional Thailand", dalam www.digilib.vin-suka.ac.id. Yogyakarta: UIN Sunan Kalijaga, t.th.

Zacharis, John C. dan Coleman C. Bender. Speech Communication: A Rational Approach. New York John Willey \& Sons, 1976 